Sotirios Tsiodras

\title{
Irregular migrants: a critical care or a public health emergency
}

Received: 28 September 2015

Accepted: 2 October 2015

Published online: 14 October 2015

(C) Springer-Verlag Berlin Heidelberg and ESICM 2015

S. Tsiodras $(\bullet)$

4th Department of Internal Medicine, Attikon University Hospital, University of Athens Medical School, 1 Rimini Str, 12462 Xaidari Athens, Greece

e-mail: sotirios.tsiodras@gmail.com

Tel.: +302105831989

S. Tsiodras

Hellenic Center for Disease Control and Prevention, Athens, Greece

Irregular migration has become a major problem for many European Union (EU) countries over the past few years. In 2014 alone, 276,113 migrants entered the EU via land, air or sea (most of them) along the southern and eastern European borders, frequently enduring perilous voyages. In $2015,520,957$ arrivals by the sea route had been recorded by the 2nd of October [1]. Overall, the number of asylum applications in the EU has increased by $75 \%$ between 2014 and 2015; they mainly come from Syria, Afghanistan, Eritrea and Iraq, all countries hit by regional instability and conflict. The flow of migrants in Europe is not constant (although lately this is changing) and at the moment not evenly distributed throughout the EU. Nevertheless, this is a dynamic situation and predictions for the countries most affected in the future cannot safely be made, as the migrants' entry modes may evolve, as well as their choice of target entrance countries. Currently, huge migratory pressures are being exerted on several Southern European countries such as Greece and Italy, leading to surge capacity issues. For example, 137,000 irregular migrants reached Greece during July and August, an increase of $250 \%$ [2]. According to the International Organization on Migration the majority of arrivals to Greece are from Syria, Afghanistan and Iraq; in Italy, on the other hand, they most frequently come from Eritrea, Nigeria, Somalia, Syria, Gambia and Sudan [3]. Two emergency schemes were recently adopted in order to relocate 160,000 irregular migrants from the $\mathrm{EU}$ member states most affected to other member states [2] (Fig. 1). The first relocation transfers are expected within 1 month of the decision [2]. Based on an EU-wide asylum recognition rate of $\geq 75 \%$, Syrians, Eritreans and Iraqis are expected to benefit the most from the current relocation scheme [2]. In addition, on 23 September 2015 a number of priority measures were laid out to be delivered within 6 months under the European agenda for migration, including significant budgetary support. An increase in the funds for humanitarian aid by $€ 200$ million in 2015 and $€ 300$ million in 2016 was agreed upon, as well as increased funding for relevant EU agencies such as Frontex, the European Asylum Support Office and Europol [2].

The goal of this fast-growing community of illegal migrants, refugees and asylum seekers is unauthorized entry, transit and/or residence in Europe, anticipating a higher quality of life. Most of the recent Syrian migrants are educated middle-class people looking for a better future abroad due to the recent turmoil in their country [4]. Their situation during migration and most of the time during the first few weeks after EU entry carries significant health risks as it appears to be characterized by social instability, continuous mobilization, poverty, and lack of food and water or essential medical supplies, as well as poor standards of hygiene. This situation has several public health implications and has forced the European Commission to include migration amongst its ten top political priorities [2]. 
Fig. 1 Relocation scheme breakdown per EU member state (adapted from figures available from the EC website [2])*. Another 54,000 would have been relocated from Hungary, but that country did not wish to be included as beneficiary of the emergency relocation scheme**. *The overall figures will be amended to take into account the participation of Norway and Switzerland. **The 54,000 not relocated from Hungary under the current scheme will be proportionally relocated from Italy and Greece or another state (should the situation change) to other member states of the EU [2]

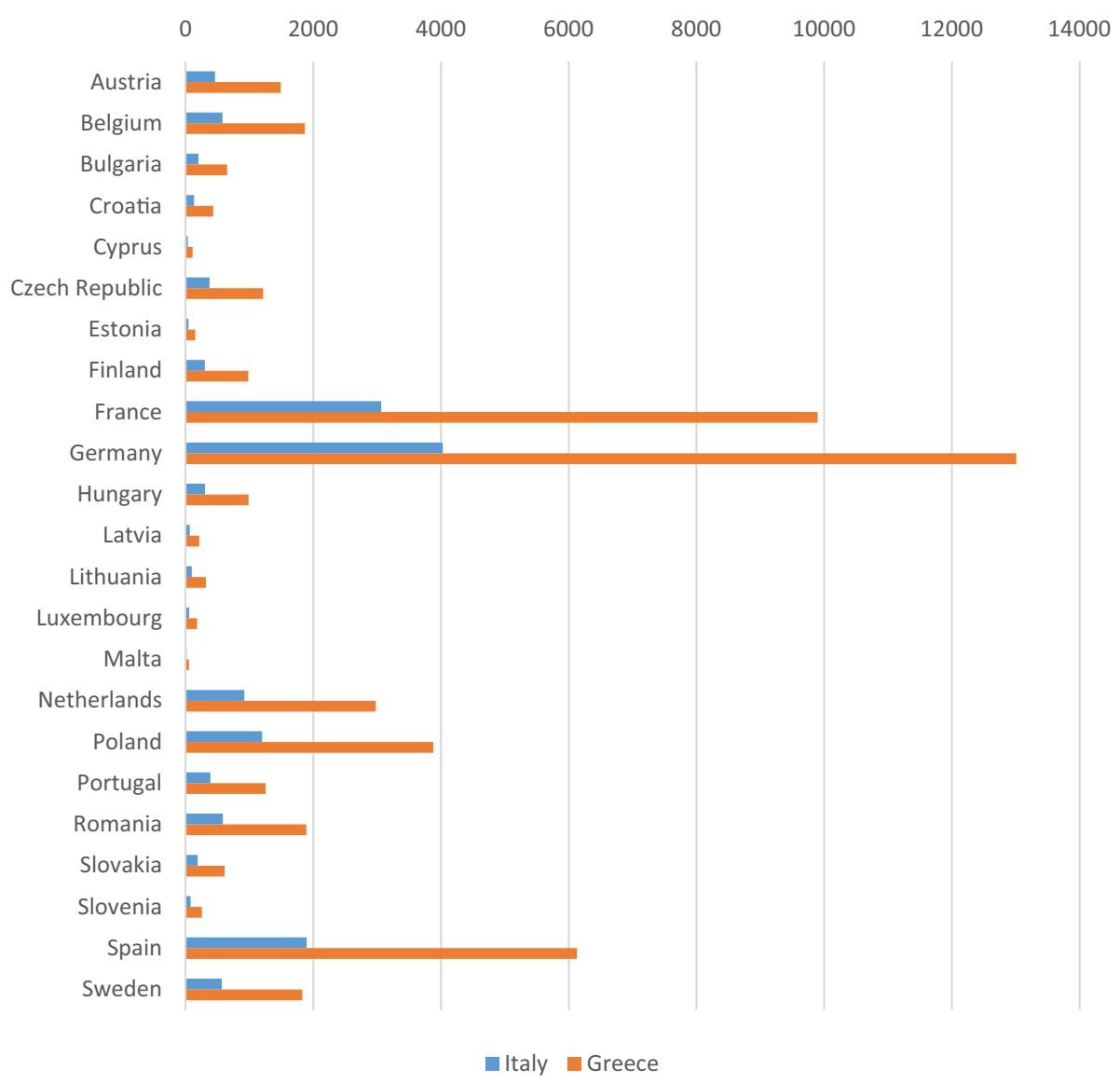

With regard to infectious diseases, it has been very challenging to correlate their occurrence among irregular migrants with the migrants' status. The association is confounded by several parameters, including: (1) the spectrum of infectious diseases affecting the migrants (depending on local endemicity in the country of origin, as well as the individual disease's potential for transmission); (2) the ever-changing patterns of migration; and (3) the presence of certain vulnerable groups within the migrant population (e.g. the elderly, the very young and pregnant women). Infectious diseases in migrants could have been acquired in their country of origin, while in transit, or after entry into a European country. Certain infectious diseases appear to be disproportionately affecting migrant populations after their entry into Europe, as shown by data from the European surveillance system operated by the European centers for disease control (ECDC); these include HIV, tuberculosis, chronic hepatitis B and parasitic diseases such as malaria, Chagas disease or schistosomiasis [5, 6]. These are chronic diseases. In some instances introduction of a disease by migrants has been associated with the occurrence of a local epidemic in the country of arrival, as was the case with a recent malaria outbreak in Greece where autochthonous cases were associated with cases in recently arrived migrants [7]. The association of migrant status with the diagnosis of vaccine-preventable diseases such as measles and rubella is not easy; migrant children are supposed to be at higher risk due to lower vaccination rates [5]. The human cases of paralytic poliomyelitis caused by circulating vaccine-derived poliovirus type 1 that were reported in September 2015 in Ukraine highlight the currently theoretical potential for introduction of polio into populations with low vaccination coverage by people arriving from an endemic country [8,9]. The same could be true for other vaccine-preventable diseases like diphtheria; isolated cases of cutaneous diphtheria among refugees and asylum seekers were reported by Denmark, Germany and Sweden in July 2015 [10]. Poor access to the specific antitoxin was a major issue recognized during the handling of these events [10]. Initial fears that an undocumented migrant might import Ebola virus into Europe proved groundless: analysis of surveillance data revealed no such cases, and the epidemic has made the transition to a third phase with very few diagnosed cases [11].

Although infectious diseases are not overwhelmingly common among irregular migrants, the overcrowded conditions in which they usually live after their EU country entry create the perfect environment for the 
propagation of an easily transmitted pathogen such as certain respiratory (e.g. influenza) or intestinal pathogens (e.g. cholera) or meningococci.

A matter of intense debate is the value of screening all irregular migrants for communicable pathogens at their time of entry. ECDC, together with EU member states, has supported measures aimed at issuing guidance on an effective infectious diseases screening procedure in newly arriving migrants [12]. Existing protocols should quickly be harmonized not only at European but at global level; isolated efforts may not always lead to comparable data $[13,14]$.

In general, irregular migrants are otherwise young and healthy. Nevertheless, the possibility that intensive care medicine (ICU) services will be required for a very small fraction of this population exists not only for infectious diseases (e.g. hemorrhagic fever, cerebral malaria or severe cases of cholera) but also for other conditions such as trauma, rhabdomyolysis, starvation and/or dehydration, acute liver or kidney injury, acute encephalopathy, heat stroke or hypothermia $[15,16]$. The European Society of Intensive Care Medicine needs to take a leading role in identifying issues related to critical care provision in the migrant population in Europe. More data are necessary to facilitate recognition of drivers for critical illness in this population, similar to efforts across the Atlantic [15]. Thankfully, due to the young age of most of the immigrant population severe disease and death appear to be rare events [15]. However, as of 2 October, 2980 wouldbe irregular immigrants to Europe had been reported dead or missing in 2015 [1].

The current crisis necessitates actions to protect the health of this highly vulnerable population in all developed countries throughout the world, not just in Europe. The first priorities should be saving lives and providing a humane reception, as well as providing access to asylum procedures and humane return conditions [2]. The continuous marine emergencies with dozens of deaths every day cannot continue. Mass casualty events relating to such emergencies may arise, leading to surge capacity issues in ICU provision. On the other hand, on top of food and shelter, the provision of sanitation, medical supplies, other non-food items and psychological/mental support is essential. Implementation and enhancement of current legislation will further improve our response. An amendment of the Dublin regulation that currently demands the registration of migrants as refugees in the first EU country they enter, together with a proposal for a structured system on resettlement, will be pursued in the next 6 months at the EU [17]. The recent adoption of 40 infringement decisions against $19 \mathrm{EU}$ member states shows that more work and readiness to assume responsibility is necessary from almost all EU countries [18].

Respecting human rights at all phases of management of the current crisis is of paramount importance. As recently stated by the European Commission, closing borders and building fences is not the solution. Thankfully, most European citizens as well as multiple civil society groups are exhibiting solidarity and unprecedented compassion, offering strong support for their harshly hit fellow humans who are often victims of grave human rights violations.

Europe needs to work closely with key organizations to help deal with the current crisis at an international level. Migration is a global phenomenon characterized by significant complexities [19]. Migrants have complex health needs that are influenced by several drivers; one of the most important is their access to health care. Further to care provision, it is essential to gather quality data on notifiable and other diseases in irregular migrants in order to determine trends, assess potential drivers and establish appropriate interventions and/or preventive measures. Innovative approaches to data collection may be more appropriate for this highly mobile population. Cleaner surveillance data will lead to the production of better risk assessment documents and guidance, with the main goal of added value at the international level.

Strengthening of financial solidarity is essential to a successful response. Austerity measures are expected to further hamper the function of prevention and treatment programmes; this will exacerbate infectious disease risks among all migrants, irregular or otherwise [20].

In conclusion, the challenges associated with refugees, asylum seekers and migrants necessitate immediate and coordinated efforts from relevant organizations and stakeholders to successfully cope with the current crisis at the European borders. Migration is not a temporary issue [19]. Our emergency response will prevent further human tragedies but will also assist in managing migration in all of its aspects in the medium and long term.

\section{References}

1. Refugees/Migrants Emergency Response-Mediterranean. The UN refugee agency. http://data.unhcr.org/ mediterranean/regional.php. Accessed 2 Oct 2015
2. European Commission-Fact Sheet. Refugee crisis-Q\&A on emergency relocation. MEMO/15/5698. Brussels, 22 September 2015.

http://europa.eu/rapid/pressrelease_MEMO-15-5698_en.htm. Accessed 24 Sept 2015
3. International Organnization for Migration. Mediterranean migrants arrive in Italy, Greece-more deaths reported. https://www.iom.int/news/ mediterranean-migrants-arrive-italygreece-more-deaths-reported. Accessed 24 Sept 2015 
4. Beehner L (2015) Syria crisis echoes 1930s anti-semitism: column. USA today. September 22, 2015. http://www.usatoday.com/story/ opinion/2015/09/22/syria-refugeesjews-holocaust-anti-semitism-column/ 72623590/. Accessed 24 Sept 2015

5. Executive summary. Assessing the burden of key infectious diseases affecting migrant populations in the EU/EEA.

http://ecdc.europa.eu/en/publications/ Publications/assessing-burden-diseasemigrant-populations.pdf. Accessed 23 Sept 2015

6. Gautret P, Cramer JP, Field V, Caumes E, Jensenius M, Gkrania-Klotsas E, de Vries PJ, Grobusch MP, Lopez-Velez R, Castelli F, Schlagenhauf P, Hervius Askling H, von Sonnenburg F, Lalloo DG, Loutan L, Rapp C, Basto F, Santos O'Connor F, Weld L, Parola P (2012) Infectious diseases among travellers and migrants in Europe, EuroTravNet 2010. Euro Surveill 17(26)

7. Danis K, Baka A, Lenglet A, Van Bortel W, Terzaki I, Tseroni M, Detsis M, Papanikolaou E, Balaska A, Gewehr S, Dougas G, Sideroglou T, Economopoulou A, Vakalis N, Tsiodras S, Bonovas S, Kremastinou J (2011) Autochthonous Plasmodium vivax malaria in Greece, 2011. Euro Surveill 16(42)

8. European Centre for Disease Prevention and Control (2015) Outbreak of vaccine-derived poliovirus type 1 (cVDPV1) in Ukraine, August 2015, 2 September, Stockholm

9. European centre for disease prevention and control (2013) Risk of introduction and transmission of wild-type poliovirus in EU/EEA countries following events in Israel and Syriaupdated risk assessment, December 2013: ECDC.

http://ecdc.europa.eu/en/publications/ Publications/poliomyelitis-riskassessment-update-10-December2013.pdf. Accessed 23 May 2014
10. European Centre for Disease Prevention and Control (2015) Cutaneous diphtheria among recently arrived refugees and asylum seekers in the EU, 30 July 2015. ECDC, Stockholm

11. World Health Organization. Ebola situation report, 23 September 2015. http://apps.who.int/ebola/currentsituation/ebola-situation-report-23september-2015. Accessed 24 Sept 2015

12. Public health benefits of screening for infectious diseases among newly arrived migrants to the EU/EAA. Technical meeting on migrant health. Athens 19-20 March 2014. http://ecdc.europa.eu/en/press/events/ _layouts/forms/

Event_DispForm.aspx?List=a89263348425-4aae-be6a-

70f89f9d563c\&ID=254. Accessed 24 Sept 2015

13. Centers for disease control and prevention. Guidelines for the U.S. domestic medical examination for newly arriving refugees. http://www.cdc.gov/ immigrantrefugeehealth/guidelines/ domestic/domestic-guidelines.html. Accessed 2 Oct 2015

14. Seedat F, Hargreaves S, Friedland JS (2014) Engaging new migrants in infectious disease screening: a qualitative semi-structured interview study of UK migrant community healthcare leads. PLoS One 9(10):e108261

15. Wong C, Hsu W, Carr GE (2015) Spectrum of critical illness in undocumented border crossers. The Arizona-Mexico border experience. Ann Am Thorac Soc 12(3):410-414

16. Pasta L, Mesa Suero LA, Farinella EM, Marchese G, Serravalle D, D'Amico N, Filippazzo MG (2015) Causes of hospitalisation of migrants arrived in Lampedusa (Southern Italy) from January 2011 to June 2014. Epidemiol Prev 39(1):55-58
17. European commission. Press release managing the refugee crisis: immediate operational, budgetary and legal measures under the European agenda on migration brussels, 23 september 2015. http://europa.eu/rapid/press-release_ip15-5700_en.htm. Accessed 24 Sept 2015

18. More responsibility in managing the refugee crisis: European commission adopts 40 infringement decisions to make European Asylum System Work. European Commission-Press release, Brussels, 23 September 2015. http://europa.eu/rapid/press-release_IP15-5699_en.htm. Accessed 24 Sept 2015

19. European parliament. Joint motion for a resolution pursuant to rule 123(2) and (4), of the rules of procedure replacing the motions by the following groups: PPE (B8 0832/2015), ALDE (B8 0834/2015), Verts/ALE (B8 0837/2015), S\&D (B8 0842/2015) on migration and refugees in Europe (2015/2833(RSP)). http://www.europarl.europa.eu/sides/ getDoc.do?pubRef=-//EP//

TEXT+MOTION+P8-RC-2015$0832+0+\mathrm{DOC}+\mathrm{XML}+\mathrm{V} 0 / /$ EN\&language $=$ en. Accessed $24 \mathrm{Sept}$ 2015

20. Kentikelenis A, Karanikolos M, Williams G, Mladovsky P, King L, Pharris A, Suk JE, Hatzakis A, McKee M, Noori T et al (2015) How do economic crises affect migrants' risk of infectious disease? A systematicnarrative review. Eur J Public Health. doi: 10.1093/eurpub/ckv151 